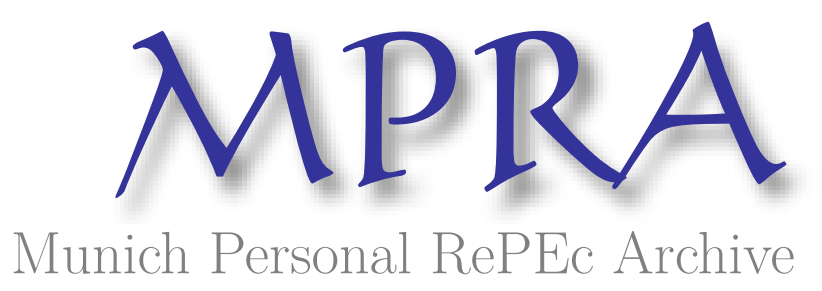

\title{
The constitutional dilemma of European integration
}

Kurrild-Klitgaard, Peter

University of Aarhus

1998

Online at https://mpra.ub.uni-muenchen.de/35437/

MPRA Paper No. 35437, posted 16 Dec 2011 23:33 UTC 


\section{The constitutional dilemma of European integration ${ }^{1}$ Peter KURRILD-KLITGAARD \\ Department of Political Science, University of Aarbus}

\section{Introduction}

An analogy is often made between the process of European integration and that of a "social contract." Here European integration is seen as a process of contracting between states similar to that between individuals in a "state-of-nature." In such a condition, the argument goes, individual actors will not be able to cooperate voluntarily and hence they will have a common interest in entering into a contract whereby they obligate themselves and each other to cooperate in the future. By doing so they will be able to realize mutual benefits.

One does not need to look far to find such interpretations of the process of European integration-particularly not among public choice theorists of a contractarian orientation, who have cheered European integration with optimism. The founding father of public choice theory and constitutional economics, ${ }^{2}$ Nobel laureate James Buchanan, for example, has put it like this:

I shall argue that Europe is now presented with an historically unique opportunity to achieve that greatness which has so long remained unrealised. Quite literally, the 1990s offer Europe a once-in-history opportunity, which, if seized, can promise greatness as defined in a mutually agreed-on dimensionality, but which, if missed, must promise disaster... . The opportunity is so clear that the folly reflected in failure to seize it is not included even within my public choice perspective on politics and politicians.

A constitution that will embody the terms of the contract that the peoples of Europe must make, one with another, individually and as members of separate national-cultural communities, is a sine qua non of the whole enterprise. But there are constitutions and constitutions, and the terms of the contract must match the corresponding historical realities. The contract must be such as to ensure mutual gains-from-trade, the ultimate test for which is voluntary agreement on the terms. And such agreement will be forthcoming only if the parties to the contract (individually, both separately and in groups) are effectively guaranteed or protected against exploitation during periods subsequent to ratification.

... The only constitutional structure that is consistent with the historicallyconstrained setting of the 1990s is that of a federal union, within which members of the separate units co-operate for the achievement of widely recognised and commonly shared objectives, those of internal (intra-European) peace and economic prosperity, within political arrangements that ensure individual liberties and, at the same time,

\footnotetext{
${ }^{1}$ I am grateful to Otto Brøns-Petersen for many stimulating discussions of the basic thesis of this paper and to Peter Nedergaard, Roland Vaubel and Anders Wivel for helpful suggestions. Only the latter has, however, read the manuscript and, for better or worse, the responsibility is entirely my own.

2 See Voigt (1997) for a survey of the rapidly evolving discipline of constitutional economics (or constitutional political economy).
} 
allow for the maximal practicable achievement of standards of justice. (Buchanan 1990: 1-2; italics in original) ${ }^{3}$

The underlying premise here is the fundamentally contractarian character of the process of European integration: It is in the mutual interest of the parties, and that is the explanation of why the integration is taking place as well as the justification of why it should take place. The purpose of this study is, however, to point towards a fundamental, yet largely ignored, problem in such reasoning in general and with reference to the European Union in particular. The basic argument will be that if the supposed reason for European integration is correct, then the proposed solution will not be possible, while if the reason is not correct, then the solution will not be necessary. In the first part of the essay I will sketch contractarianism and its problem in a general form, while in the second I will demonstrate how it is potentially relevant for the process of European integration and then ask why European integration takes place at all and why it takes the form it does. Finally I will briefly indicate how the insights developed here may be seen as pointing towards a constitutional dilemma for the process of European integration.

\section{A "Contractarian Paradox"}

In recent decades a renaissance has occurred for the political theory of contractarianism, notably spearheaded by the works of John Rawls (1974) and James Buchanan (1975). In this movement contemporary theorists have given new life to the old tradition by employing modern analytical tools, e.g., those of so-called game theory, such as it has been done explicitly in the case of the theories of Thomas Hobbes. ${ }^{4}$

\section{The Prisoners' Dilemmas of the state-of-nature}

The essence of the contractarian perspective is to show that a social condition without any central authority would be so undesirable in terms of some generally accepted standard that everybody would prefer the creation of a political authority. Of the classical contractarians Thomas Hobbes and Hugo Grotius, e.g., identified "peace," understood as domestic social order, security of property rights and defense against external aggression, as what today would be termed a "public good" of a quite fundamental kind since without it most other "goods" would not be possible (at least in the long run). Samuel Pufendorf similarly identified the promotion of "sociality," understood as cooperation and mutual respect for rights, as the "fundamental natural law," since that was what would enable men to successfully pursue other ends. Finally, John Locke identified "justice," understood as the lack of violations of the individual's natural right to freely pursue his self-

\footnotetext{
${ }^{3}$ For a quite similar, but more recent, perspective, see, e.g., Mueller (1997: 278).

4 This has been done, though with slightly different emphasis and somewhat different conclusions, by, e.g., Kavka (1986: Chs. 3-6), Hampton (1986: Chs. 2-3, 5-6) and Taylor (1987: 125-63).
} 
preservation through the use of his property, as a "public good." 5

However, in a "state-of-nature" where there is assumed to be nothing to make individuals pursue "peace," "sociality" or "justice" other than their own self-interest, individuals will have a choice not between outcomes but between strategies for how to act. In Hobbes' state-of-nature an individual would have a choice between a strategy of "peace" and one of "war", and in Locke's state-of-nature transformed into a state-of-war, he would have a choice between respecting the natural rights of others or of violating these. Let us for the present purposes assume that "peace" or "justice" are synonymous with the universal respect of established property rights of others; in that case the possible choice-sets of the individuals can be subsumed under two general strategies: Respecting or violating property rights. ${ }^{6}$

In a two-person setting each individual will plausibly prefer to have property rights respected in general to having them violated in general; in particular he will probably prefer having his own property rights respected to having them violated. But he will also ceteris paribus prefer to violate rather than respect the property rights of the other person, and this additional feature is what gives the interdependent situation its particular character. The strategic character is illustrated in the bimatrix of Figure 1, which gives the available strategies, the possible outcomes and the relative preference orderings over these by the respective players, with 1 as the most and 4 as the least preferred outcome. ${ }^{7}$

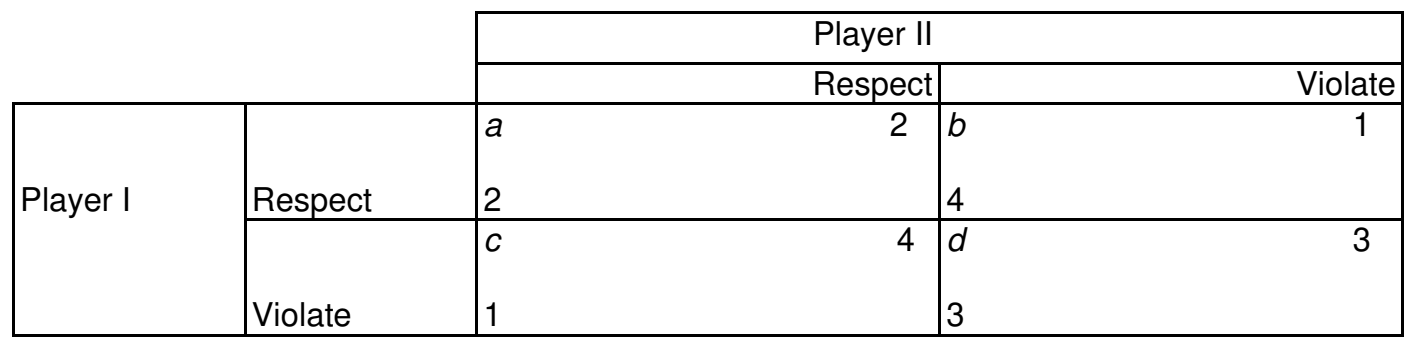

Figure 1. Interaction in a state-of-nature

If we use the analytical tools of game theory to model the situation, as done in the figure, the situation will be identical to the so-called "Prisoners' Dilemma" game, which in recent decades has become by far the most popular way to illustrate the problems facing the individuals in a state-of-nature. ${ }^{8}$ In this situation each individual prefers a situation where everyone respects property rights, i.e. $(R R)$ in cell $a$, to one where nobody respects property rights, i.e. (VV) in cell $d$. But it is

${ }^{5}$ On these points, see, e.g., Hobbes ([1651] 1991, Chs. 13-15: 86-111), Pufendorf ([1673] 1991, I, Ch. 3, \$\$7-9: 35-36) and Locke ([1690] 1988, II, \$17: 279).

${ }^{6}$ Cf., e.g., Pufendorf ([1672] 1934, VI: Ch. 4) and Locke ([1690] 1988, II: Chs. 2-3).

${ }^{7}$ For similar uses of the Prisoners' Dilemma game to illustrate the fundamental character of the interaction of the state-of-nature, see, e.g., Buchanan (1975: 26-28, 64-68), Hampton (1986: 61-63) and Kavka (1986: 109-12).

${ }^{8}$ See, e.g., Barry ([1965] 1972: 253-54), Tullock (1974: 2, 11-16), Buchanan (1975: 26-28, 64-68, 13046), Hampton (1986: 61-62, 75-93, 132-39, 225-32), Kavka (1986: 109-13, 124-40, 146-47, 154-56, 245-46), Schmidtz (1991: 57-85). Rawls also uses the Prisoners' Dilemma in order to illustrate the argument for government provision of public goods (Rawls 1971: 269). It is also often used in reviews of contractarian arguments in order to illustrate these, see, e.g., Green (1988) and Kraus (1993). 
simultaneously the case, that each individual prefers to have his property rights respected while not respecting those of other individuals, i.e. (VR) in cell $c$ and (RV) in cell $b$ for player I and II respectively. This structure of the preferences means, that any individual, who in this situation unilaterally chooses to respect the property rights of others will open himself up to-and be submitted to-predation. It also means that the rational strategy for each individual is to choose not to respect property rights, and to do so no matter what strategy other individuals might choose, and thus that the equilibrium is an outcome, where nobody respects property rights, namely $(V V)$ in cell $d$.

If the interaction between the two individuals is repeated over time, then some mutual recognition of and respect for property rights might evolve as a norm, but with symmetric preference orderings, no external sanctions imposed for violations, attempted utility-maximization and shortsightedness, the interaction will have the character of a single-play game. In the absence of any enforcement mechanism it will be irrational for any individual to perform his part of a contractual obligation first. ${ }^{9}$

This situation may be seen to be generalized into the generation of a "war of all against all," and there are, at least, two reasons for this. First, the situation is one common to all individuals faced with any human interaction in the state-of-nature, since all action necessarily involves the use of scarce resources and hence property rights in some form. It will in other words not only characterize the interaction of some particular two individuals, but potentially all the interaction of all individuals. Second, any suggested solution to these forms of interpersonal conflicts will constitute a collective action problem, because the protection of rights itself is a public good. This is so, because while all members of society may agree, that they would all be better off if they respected each others' rights, there is a latent conflict between what is individually rational and collectively rational when it comes to actually voluntarily providing the public good of "peace" or "justice." If for example the securing of "peace" or "justice" is simply seen as the outcome of the individuals voluntarily changing their behavior from violating each others' rights to respecting these, and if there are no changes in the preferences of the individuals, then the choice-set of the separate individual will nonetheless still be that of the bimatrix of the figure.

\section{The contractarian argument}

A general version of the argument of political contractarianism could be seen to go like this: Rational individuals in the state-of-nature will realize, that the public good will only be produced if they simultaneously give up their ability to violate the rights of others and do so by empowering an institution with a monopoly on the use of coercive force so as to make it possible to enforce solutions.

Hobbes, for example, argued, that every individual in "the natural condition of mankind" guided by reason will come to realize the "fundamental law of nature,"

\footnotetext{
${ }^{9}$ See, e.g., Hobbes ([1651] 1991, \68: 96-97). See also Hampton (1986: 62-63).
} 
which is, "to seek Peace, and follow it," and accordingly, as the second law, "be willing, when others are so too, as farre-forth as for Peace, and defence of himselfe he shall think it necessary, to lay down this right to all things" (Hobbes [1651] 1991, \$65: 92). Accordingly each individual in the state-of-nature must make a covenant with every other individual, in which it is mutually promised to give up the right of self-defense by relinquishing that and all other rights to a political authority to be created, either stipulated in each covenant or chosen by a majority. The political authority thus created has the obligation to secure internal and external peace and is unconstrained. ${ }^{10}$

In a related, but somewhat different way, Locke argued that political authority is justified as a remedy for an efficient and just enforcement of property rights by the restraining of violence. But since injustice may also occur under an unconstrained and sovereign political authority, this can only be created by consent and only and solely by giving up those rights, which are necessary for the provision of the public good. ${ }^{11}$ Pufendorf similarly saw the institution of political authority as necessary for securing and further increasing the already created socially beneficial institutions; if "sociality" is not so secured, there is a risk, that the seeking of selfpreservation by individuals will endanger it. Pufendorf therefore envisioned that individuals in the state-of-nature voluntarily will form a two-stage social contract, whereby it is decided to institute political authority and the form of it. ${ }^{12}$ Of contemporary political contractarians James Buchanan (1975) has similarly outlined a strictly logical social contractual process also consisting of two stages (or levels), whereby individuals out of consideration of their own utility-maximization are seen as unanimously agreeing on the assignment of property rights and provision of public goods, first and foremost the protection of rights. ${ }^{13}$

What, despite their differences, unite these contractarian theories is, that the purpose of the social contract is to create political authority, since it is assumed, that the institution of a organization with the ability to enforce solutions will mean a more successful, i.e., efficient, provision of such public goods as, e.g., "peace" and "justice." This may be illustrated as done in the bi-matrix in Figure 2.

\begin{tabular}{|c|c|c|c|c|c|}
\hline & & & er II & & \\
\hline & & & pect & & Violate \\
\hline & & $a$ & 1 & $b$ & 3 \\
\hline Player I & Respect & 1 & & 2 & \\
\hline & & c & 2 & $\bar{d}$ & 4 \\
\hline & Violate & 3 & & 4 & \\
\hline
\end{tabular}

Figure 2. Interaction after social contract

Here the political authority created by the social contract has succeeded in

10 See Hobbes ([1651] 1991), especially Chs. 14-15. Grotius' position was close to Hobbes', but much less developed, see, e.g., Grotius ([1625] 1901: 63-68).

${ }^{11}$ Cf. Locke: The "great and chief end . . . of Mens uniting into Commonwealths, and putting of themselves under Government, is the Preservation of their Property." (Locke [1690] 1988, II, \124:

350-51). For other central passages, see (Locke [1690] 1988, II, §15: 278; §95: 330-31; §99: 333).

12 On these points, see especially Pufendorf ([1672] 1934, VII: Ch. 2; [1673] 1991, I, Ch. 3, §7: 35).

13 For Buchanan's slightly abstract and complicated scheme, see Buchanan (1975: 17-73). 
imposing sanctions upon those, who do not respect the property rights of others and thus successfully changed the preference orderings of the individuals so as to induce them to cooperate. Accordingly there now is a unique equilibrium, which is identical to the collectively preferred outcome in the Prisoners' Dilemma, i.e., (RR) in cell $a$. The argument of political contractarianism, so broadly conceived, may be summarized as done by the propositions in Table $1 .{ }^{14}$

Table 1.

(P1) If political authority is necessary to enforce a supply of solutions to public good problems, then rational individuals will consent to the creation of political authority.

(P2) Rational individuals in a state-of-nature will not cooperatively supply solutions to public good problems.

(P3) Political authority is necessary to enforce a supply of solutions to public good problems in a state-ofnature.

Therefore

(P4) Rational individuals in a state-of-nature will consent to create political authority to enforce a supply of solutions to public good problems.

The essence of the argument contained in these propositions typically characterizes contemporary versions of political contractarianism, be they explanatory or justificatory and assuming that the consent is hypothetical or actual (whether explicit or tacit). In explanatory versions of political contractarianism the inference will be, that the historical origin of existing states can be explained as the outcome of such a process, i.e., that individuals in a state-of-nature have consented to the creation of political authority. ${ }^{15}$ Similarly in justificatory versions of political contractarianism the inference will typically be, that political authority is justified, because it can be seen as being the outcome of what rational individuals freely would consent to.

\section{The "Possibility Problem" and the "Necessity Problem"}

There are several problems inherent in using the Prisoners' Dilemma analogy in a political contractarian context. I shall not treat these problems here, but neither shall I claim, that the Prisoners' Dilemma is the only (or best) way to model the interaction of the state-of-nature. ${ }^{16}$ For while several theorists have had important

14 This presentation owes much to Schmidtz (1990: 95; 1991: 8).

15 Whether the consent in question has been actual (be it expressive or tacit) or hypothetical is not necessarily assumed to be important; what is posited as important, is that the origin of states may be modeled "as if" consent had been given.

16 There may indeed be good reasons for why it should not be seen as being adequate, and for why the provision of public goods in a state-of-nature rather should be seen as constituting such "milder" collective action dilemmas as, e.g., the games called "Chicken", "Assurance" or "Battle of the Sexes.", cf., e.g., Taylor (1987: 18-19 \& 31) and Hampton (1987). Personally I do not believe, that the Prisoners' Dilemma in general adequately captures the interaction typical of real-life situations without enforced solutions or those of a state-of-nature. It may do so, but I think that its relevance is much less pervasive, than political contractarians claim. Quite often the identification of what allegedly is a collective good, is less than accurate, yet the problem only applies strictly to completely "pure" public goods, i.e., goods which are purely non-excludable in consumption and purely joint in supply. If they are not so, their provision does not necessarily constitute a Prisoners' Dilemma and not even necessarily a collective action dilemma. Ronald Coase, for example, showed, that the most popular classical example used by economists to illustrate a typical collective 
things to say about these questions, and while these are highly relevant for the question of the general applicability of the Prisoners' Dilemma, it is not the problem which I want to address. Rather than to try to show that political contractarianism is wrong in modeling the interaction of the state-of-nature as something similar to a generalized version of a two-person single-play Prisoners' Dilemma, I shall simply take the assumption that this is a valid procedure for granted and then proceed to show, that this, nonetheless, itself poses a much deeper problem for political contractarianism. For while political contractarians have labored hard to explain the disadvantages of the lack of cooperation in the state-of-nature and the advantages of cooperation made possible by the creation of political authority, they have spent little or no time addressing the very important question of how it can be possible to reach the cooperation necessary for the creation of political authority itself. Yet, my claim shall be, that political contractarianism, when it is based on the Prisoners' Dilemma, necessarily will fail in what must be its most important pursuit, namely to simultaneously explain, how the state-of-nature can be so problematic as to make the creation of political authority necessary but not so problematic as to make this logically impossible. ${ }^{17}$

The potential existence of such a problem has already under various labels and to varying extents been identified by a few theorists, particularly as it may apply to arguments in favor of government enforced solutions to public good problems and similar situations resembling other two- or $n$-person Prisoners' Dilemmas. ${ }^{18}$ But while the possibility of such a problem has been identified, it has in my opinion neither been given the attention which it deserves, nor been explicitly related to its full potential implications for political contractarianism. I will, in contrast, argue here that a political contractarianism based on the use of Prisoners' Dilemma reasoning is faced with what could be called the "Prisoners' Dilemma of the

good, the lighthouse, is not a "pure" public good, and actually has been supplied by the market. Rothbard ([1970] 1977) and a number of other economists have similarly shown, that a large number of even the most "traditional" collective goods - the hard cases-are not necessarily so.

17 Cf., e.g., Schmidtz (1990: 93-94), Hampton (1986: 74-79, 136-37), Green (1988: 147-48) and Kraus (1993: 11, 17-18, 38).

18 Of contemporary theorists Kalt (1981: 577-84) speaks of a "paradox" of the "public goods theory of the state" while Bates (1988: 394-95) and Ostrom (1990: 42-43) speak of the "problem of supply" of public goods and the possible existence of "second-order collective dilemmas." The treatments of the problem closest to the present are those of Hampton (1986), Green (1988) and Cowen and Kavka (1991) of which the first and the last try to solve the paradox. In an elaborate treatment Green (1988: 122-57), in contrast, uses the paradox to reject political contractarianism. Green presents the paradox in a way quite similar to the present, i.e., he identifies implicitly what is here termed the "necessity problem" and the "possibility problem" and speaks of a "Prisoners" Dilemma Dilemma" and of a potential "string of higher-order PDs." Hampton (1986: 69-79) has in a reconstruction of Hobbes' argument pointed toward a similar problem in Hobbes' account of the character of the state-of-nature and the institution of absolute sovereignty. Cowen and Kavka (1991: 1-2) speak of a possible "circularity problem" in the public goods argument for government intervention and supply of public goods. For somewhat related discussions, see also, e.g., Taylor (1987), Hampton (1987), Narveson (1988: 139-40) and Schmidtz (1988; 1990). I have myself treated the paradox briefly in Kurrild-Klitgaard (1997). 
Prisoners' Dilemma," but which here is best described as a Contractarian Paradox. ${ }^{19}$

The problem can potentially take two forms, which, however, seem to be but different sides of the same underlying problem and both stemming from the same line of reasoning, namely the assumption in the single-play Prisoners' Dilemma of the players being not just handicapped in their communication but incapable of communicating, imposing mutual sanctions, etc. To see this one may consider the argument given by the propositions (P1), (P2), (P3) and (P4), as well as their logical alternatives (P1'), (P2'), (P3') and (P4') of Table 2.20

Table 2.

\section{Proposition}

(P1) If political authority is necessary to enforce a supply of solutions to public good problems, then rational individuals will consent to the creation of political authority.

(P2) Rational individuals in a state-of-nature will not cooperatively supply solutions to public good problems.

(P3) Political authority is necessary to enforce a supply of solutions to public good problems in a state-of-nature.

Therefore

(P4) Rational individuals in a state-of-nature will consent to create political authority to enforce a supply of solutions to public good problems.

\begin{abstract}
Negation
(P1') If political authority is necessary to enforce a supply of solutions to public good problems, then rational individuals will not consent to the creation of political authority.

(P2') Rational individuals in a state-of-nature will cooperatively supply solutions to public good problems.

(P3') Political authority is not necessary to enforce a supply of solutions to public good problems in a state-of-nature.

(P4') Rational individuals in a state-of-nature will not consent to create political authority to enforce a supply of solutions to public good problems.
\end{abstract}

The problems of this line of reasoning come into effect, once two implicit assumptions_-which indeed quite often are claimed explicitly in political contractarianism-are realized: That political authority itself, according to the argument, must be a public good, and that the cooperative supply of the public good (the consent to create it) hence itself may constitute a collection action dilemma. This must necessarily be so, since it is both assumed, that the existence of an enforcing political authority is a necessary prerequisite to overcoming public good problems (P3), yet also that this can be created cooperatively (P4). Given that this is the case, then the first version of the problem comes into action, when it is argued that rational individuals in the state-of-nature cannot overcome public good problems (P2). If that is the case, then they cannot, as concluded in (P4), cooperatively create political authority either, which is — at least implicitly_-assumed to be a public good itself (P3). This we might call the "possibility problem" of the social contract.

The second version of the problem occurs, if on the other hand it is argued, that rational individuals in the state-of-nature actually can create political authority (P4). If that is the case, then public good problems can be overcome cooperatively without being enforced, i.e., (P2'), and hence there is no need for political authority.

19 I have elsewhere called this the "Prisoners' Dilemma of the Prisoners' Dilemma" (KurrildKlitgaard 1995; 1997).

20 Notice that $(\mathrm{P} 1)$, (P2) and (P3) $\rightarrow$ (P4) is what is usually argued in political contractarian arguments, such as already outlined. It is, however, not claimed here that (P1'), (P2') and (P3') $\rightarrow$ $\left(\mathrm{P}^{\prime}\right)$; these do not constitute an argument but are merely considered to be the corresponding logical negations of the propositions (P1), (P2), (P3) and (P4). 
This we might, on the other hand, call the "necessity problem" of the social contract.

In other words, the essence of these two problems is that since, on the one hand, (P2) $\rightarrow$ (P4'), then (P4) cannot be true, while, on the other hand, since (P4) $凶(\mathrm{P} 2$ '), then (P2) cannot. There are, at least, two important implications, which follow as corollaries to the two sides of the Contractarian Paradox. First, if political authority can be created cooperatively (P4), then it cannot itself be a public good, as assumed (P3), i.e., (P3'). Rather it must be the case that it is something different, namely some form of a private good. But, secondly, if the political authority really is a public good, then it cannot be created cooperatively for the purpose of supplying solutions to public good problems but must be created non-cooperatively. The Contractarian Paradox may now, in short, be summarized as such: If a social contract is necessary, then it is not possible; but if a social contract is possible, then it is not necessary.

\section{Explaining European integration}

The Contractarian Paradox identified here may at first seem as simply a philosophical puzzle. It should, however, after a little reflection, be possible to see that it potentially has quite interesting consequences for the way we explain the process of European integration.

\section{The rationality of integration}

Most fundamentally it should be acknowledged that the arguments used to explain (and justify) the process of European integration quite often resemble such a contractarian argument, be it in everyday political discourse or in more theoretic analysis. $^{21}$ The European states are viewed as if they were players in a game, where they only act out of their relatively narrow national self-interest, thus producing negative externalities (trade restrictions, subsidies, pollution, etc.) or in other ways producing various types of collective goods in sub-optimal amounts (e.g., law enforcement). As such they are seen as being unable to cooperate voluntarily and successfully, be it bilaterally or multilaterally, and the result is a situation reminiscent of an $n$-person Prisoners' Dilemma game, i.e., where the states continuous employ sanctions, counter-sanctions, etc. But realizing that this is a counter-productive process, the states may come to realize that there are gains to be reaped from agreeing to settle on a cooperative strategy and work together, i.e., by entering into a process of integration. ${ }^{22}$

Now, such a line of reasoning tells us why an outcome like this might be a desirable outcome; it does, however, tell us little or nothing about why it should be

${ }^{21}$ Cf., e.g., Buchanan (1990), Hosli (1995) and Mueller (1997).

${ }^{22}$ For such a conceptualization of the question, see Hosli (1995: 64ff). 
expected to be the actual outcome. ${ }^{23}$ For if the European states really were unable to cooperate in a "state-of-nature" prior to the European Union because they were too narrowly self-interested, then there would seem to follow two important questions from considering the "possibility problem" of the Contractarian Paradox: (1) How were they able to cooperate voluntarily to form the European Union?; and the corollary: (2) Why should we expect actors to be any less narrowly self-interested and their interaction any less sub-optimal "inside" the Union than prior to its establishment? These questions are largely ignored in most semi-contractarian analyses of the process of European integration, which rather proceed hastily with prescriptive suggestions of the desirable solutions. ${ }^{24}$

On the other hand, there is also the more explicitly normative question which would seem to arise from considering what I have called the "necessity problem" of the Contractarian Paradox: If, as is obvious, European integration actually can take place, then the states apparently can cooperate, and why, we may ask, would it then be necessary to create a formal Union? Why would it not be sufficient to remain in a pan-European "state-of-nature"? There may, of course, be many good consequentionalist reasons why it would be desirable to have a European Union, and many such arguments have indeed been put forward. But the question posed here highlights an important perspective, which all too often remains tacit in contractarian arguments, when these are used to justify particular solutions: That the normative content of contractarian arguments really is of teleological character and not, as they would often like to be seen, of an emergent character. ${ }^{25}$

The relevant question would thus seem to be: If the dilemma posed here is accepted, then how can we explain the phenomenon of European integration, which, after all, has been such a visible feature of European politics in the 1980s and 1990s? While I have so far been critical of the answers given by some public choice theorists, this should not be misunderstood as a rejection on my part of the approach itself. Quite on the contrary, I do believe that the public choice tradition has a perfectly good intellectual tool kit with which to explain the process of European integration, but it is one which is different from the otherwise closely related tradition of political contractarianism. This perspective on European integration is relatively novel, and for the present purposes only some very general indications can be made. ${ }^{26}$

${ }^{23}$ In all fairness it should be noted that, e.g., Mueller acknowledges that the contractarian analysis really is "a normative description of what government ought to do, not a positive description of what real governments actually do." (Mueller 1997: 257; italics partly in original).

24 These issues, although formulated in slightly different way, are central to the debate on international cooperation between neo-realists and neo-liberals which dominated the discipline of International Relations in the late 1980s and early 1990s. A number of the most influential contributions to this debate are collected in Baldwin (1993).

${ }^{25}$ For a discussion of teleological and emergent justifications of political institutions, as well as an important analysis of the inherently teleological character of contractarian arguments, see Schmidtz $(1990 ; 1991)$.

${ }^{26}$ For various attempts at applying rational choice/public choice theory for the explanation of the process of European integration, see, e.g., Teutemann (1990), Nedergaard (1991; 1995), Vaubel 


\section{The logic of politics}

Rather than seeing European integration as the outcome of actors cooperating voluntarily in order to supply collective goods, we should perhaps see it as the outcome of exactly the opposite process: That of actors engaged in obtaining socalled "rents," i.e., the private goods which an individual may gain from investing his own resources in redistributing resources from others to himself through the political process. ${ }^{27}$

There are two obvious reasons why this might be a more sound explanation. One is that the assumption of selfish behavior by the actors already is underlying the argument for why cooperation would be desirable in the first place. Another is the simple fact that essentially all politics, no matter its specific form, may be conceptualized as a question of the redistribution of rents. Politics may perhaps occasionally be what text-books see it as supposedly being all about, the production of collective goods, but even if one could imagine politicians producing a completely "pure" public good, there would still be differences in the net-value of this to the individual citizens. Most of the time politics would, indeed, seem to be about the production of less than "pure" public goods, i.e., goods which are asymmetrical in their distribution of costs and benefits. The costs and/or benefits of a given action are asymmetrical when there is a difference in how relatively concentrated the costs and benefits are dispersed among individuals, so that for some the net-benefits are larger than for others. It is, for example, usually the case that an increase in public expenditure (1) benefits less than all citizens of a state and (2) is financed through general taxes. In that case the benefits are relatively concentrated and private in character, while the costs are relatively dispersed and "collective" in character. In contrast, it is usually the case that with a decrease in public expenditure the costs of the policy are concentrated while the benefits (in terms of lower taxes) are widely dispersed. ${ }^{28}$ Whenever, actually or potentially, asymmetric benefits exist, some actors will have an incentive to invest resources in obtaining them for themselves, or in preventing others from imposing asymmetric costs on them, and the more concentrated the rents the larger the incentive to seek them. For even if actors are not motivated exclusively by selfish motivations all of

(1994; 1995; 1996; 1997), Hosli (1995) and Mueller (1997). Each of these authors emphasize slightly different parts of the research program, just as they study different aspects of the process of European integration, and occasionally reach different, although largely compatible conclusions.

${ }^{27}$ As such a rent is both similar to and different from the profit sought after by entrepreneurs in the market process: It shares with it the feature that it is a net-benefit to an individual from investing resources, but it differs in that it is a redistribution of resources from some individuals to others through the coercive organization of the state. For introductions to and surveys of the theory of rent-seeking, see Tollison (1982) and Tullock (1993).

${ }^{28}$ On the concept of asymmetry, see Olson (1965), who uses it implicitly, and Kristensen (1980) who does so explicitly. For studies of the historical expansion of the public sector employing the concept, see, e.g., Kristensen (1987) who has studied transfers and expenditures in general, and Christensen (1991) who has studied regulation. 
the time, they may have to engage in rent-seeking simply to defend themselves from the rent-seeking activities of others.

The specific character of the rents pursued may vary; they may, e.g., take the form of pecuniary benefits, but in the case of political actors they may also often be seen as including non-pecuniary goods such as power, perquisites and prestige. In the public choice theory of rent-seeking the following types of actors and behavioral assumptions are typically made on the basis of such differences:

- Voters, which are seen as seeking to maximize the special benefits and privileges to them as individuals,

- Interest groups, which are seen as seeking to obtain rents through protection, regulation and subsidies, e.g., in the form of tariffs, trade and entry restrictions, licenses, contracts, direct transfers, etc.

- Bureaucrats, who are seen as seeking to obtain power, pay, perquisites and career possibilities by seeking to maximize their organization budgets and responsibilities,

- Politicians, who are seen as seeking to obtain and maintain their power by seeking to maximize votes

Voters and interest groups demand policies, while politicians and bureaucrats supply political decisions and implementations, and where supply and demand intersect policies are made. As it has been aptly put: "The iron law of rent seeking is that whenever a rent is to be found, a rent seeker will be there trying to get it." (Mueller 1989: 241). Exactly what the equilibrium outcome will be is, however, dependent upon the strength of the demand and the relative strength of the actors acting as suppliers. The particularly important point here is that it is not-as in, e.g., Marxist theory - a question of a claim that one "class" is systematically and universally exploiting another. Rather it is a game which may be repeated infinitely but with the players wholly or partly changing sides.

The standard prediction of the public choice theory of rent-seeking is that when such rent-seeking takes place, government activities exceed what is necessary on simple welfare terms. At the same time rent-seeking is seen as creating a loss in welfare-a so-called "Tullock loss"-because resources are diverted away from productive purposes to the non-productive activities of rent-seeking and protection against predation from others.

\section{The logic of European integration}

If the theory of rent-seeking is correct then we should expect European integration to have very little to do with the supply of collective goods and very much, or everything, to do with the supply of private goods. To consider this we may ask the question of what actors could be seen as having a particular special interest in increasing (or decreasing) European integration. Circumstances do not permit an 
extensive analysis, but we may briefly indicate the relevant possibilities and reasoning of some of the central types of actors. ${ }^{29}$

Some of the organized interest groups in Europe have an extremely asymmetric interest in increasing integration. This is especially the case for those representing mutual interests throughout the European Union, e.g., producer groups, trade unions, business associations and professional associations. Such groups will be able to receive more attractive subsidies, regulation and protection from the European Union than from the national governments, i.a., because centralization reduces the transaction costs of rent-seeking, or because the Union is less constrained than the individual states.

The bureaucrats of the central administration of the European Union, i.e., first and foremost the Commission, have a very strong asymmetric interest in increasing European integration, in particular the budget. But in addition to administering the Commission also takes a direct and central part in the legislative process itself, where it has the important role of agenda setter, just as it can bring cases before the European Court of Justice. As such the members of the Commission and their employees have an asymmetric ability to increase their own power and prestige, i.e., in expanding their own organizations, budgets, functions, personal benefits, etc.

The judges of the European Court of Justice have an asymmetric interest in increasing their power and prestige, e.g., by increasing the number of issues to be decided at a Union-level and the scope of the jurisdiction of the European Union.

The politicians of the European Union, i.e., the members of the European Parliament, have a relatively limited influence, but the influence which they do have is systematically geared towards strengthening the centralization of decision-making. As such the MEPs have an asymmetric interest in increasing the expenditures and jurisdiction of the parliament, since this is the way to increase their own power and prestige, i.e., their jurisdiction, budgets, personal benefits, etc.

Some of the national politicians and bureaucrats of the individual member states, i.e., the governments which are represented in the Council of Ministers, may have an asymmetric interest in increasing European integration. This may be the case, e.g., if the activities at the Union-level are not in competition with national policy goals but complementary, or if they have the expectation that a particular program will lead to a net-redistribution in favor of their country (or just important interest groups in their country), or if they have a personal interest in a career at a supranational level.

What these points indicate is that there would seem to be a set of actors who are highly influential, and who each have a systematic, vested interest in increasing European integration, and notably one which is not based in any considerations of general welfare. What drives the process of European integration would then be the extent to which it is possible for such groups to formulate policies which may obtain the support of the necessary players, and what gives a policy its specific

${ }^{29}$ Cf., e.g., Teutemann (1990: 3ff), Vaubel (1994: 153ff; 1995: 36-51) and Nedergaard (1995: 120ff), which contain more elaborate public choice models of the relevant actors in the process of European integration. 
content is, as previously indicated, the interaction between the central actors and the relative intensity of their utility from various courses of action.

It is at this point that the crucial question of the asymmetric character of costs and benefits of the political process re-enters the picture, for there would seem to be good reasons why we should expect the asymmetries to be more extensive at a European level than at national levels (Peirce 1991b; Hosli 1995). ${ }^{30}$ One reason is that the potential rents to be reaped would seem to be much higher for many special interest groups at the Union-level than at the national level. A second is that the decision-makers-the Commission and the Council of Ministers - may be seen as being much less restricted by, e.g., monitoring and public opinion than national governments. It is, on the other hand, a fact that the number of citizens to pay for transfers through taxes is much larger in the Union as a whole than in any of the individual countries, which means that any new taxes introduced at the Union-level may come to seem insignificant for the individual.

If this is correct, then the logic would seem to systematically favor "narrow" interests. We should expect interest groups to consistently press for increases in protection, subsidies and regulation, because these will constitute rents for them, while the bureaucrats and politicians will supply such, because it will mean an increase in their own power, just as we should expect the judges who can determine the boundaries of policies to allow for as wide interpretations as possible. We should thus expect European integration to be driven by continuous increases in public expenditure, programs and regulation, while the programs are financed by relatively "invisible" taxes.

So while "narrow" interests may have a strong interest in increased European integration, the "broad" interests may in contrast be seen as being systematically under-represented in the process of European integration. The reason is the simple that as the European Union contains more "ordinary" individuals than the individual member states, there may be expected to be larger collective action problems when it comes to mobilizing "general" interests. We should, for example, expect voters to be generally uninterested in the process of European integration as such, and hence badly informed about it too, i.e., to be and remain "rationally ignorant." We should also expect relatively general interest groups trying to represent consumers and taxpayers to be wholly or almost absent from the scene. So we should, for example, not expect to see, e.g., legislation lowering the taxes of European taxpayers generally, e.g., by abolishing the CAP. Neither should we expect anyone in the public in general to press for, e.g., the abolishment of particular tariffs or the repeal of subsidies (Nedergaard 1991: 159; 1995: 129). We should finally also not expect anybody-except the most marginal and insignificant groups - to work for a general decentralization of Europe, i.e., a political deintegration. Such a policy would not be especially beneficial for anyone in particular but very harmful to some quite easily identifiable groups.

Centralization may in this way seem to be an almost self-supporting process: The more centralized the decision-making and the more concentrated the benefits

${ }^{30}$ For an application of the concept of asymmetry to the study of a particular policy in relation to the process of European integration, see, e.g., Nedergaard (1995). 
to be redistributed, the larger the incentive to engage in rent-seeking. So, all in all, we should expect that rent-seeking and lobbying activities will be larger, and accordingly redistribution from the large to the small to increase-at least as long as there is no change in the institutional set-up, i.e., in the constitutional structure of the European Union.

As it turns out there seems to be considerable empirical evidence that a public choice explanation of the process of European integration is valuable. ${ }^{31}$ Asymmetries may indeed be seen to be particularly strong in exactly those areas, where European integration has been remarkable in the 1980s and 1990s, i.e., areas of protection, regulation and subsidies (Nedergaard 1991: 159; 1995: 128ff). In this respect it is particularly worth noticing that - contrary to the stated intentions - the creation of the Internal Market actually seems to have increased the asymmetric influence among interest groups (Teutemann 1990). Evidence shows that, as it has been aptly formulated, "the European Community has specialized in the supply of privileges to interest groups." (Vaubel 1994: 175). Special interests have become increasingly mobilized, ${ }^{32}$ and the vast majority of the ecus spent by the European Union are for transfers rather than collective goods. ${ }^{33}$ Given this it should come as no surprise that the bureaucracy has expanded dramatically. ${ }^{34}$

\section{Europe's constitutional dilemma}

If the public choice perspective is correct about what drives European integration, then it would seem natural to take a closer look at the possibilities for institutional reform. Indeed, for the European Union it is obvious that the power is simultaneously extremely loosely defined and rather centralized. As such the current constitutional order of the European Union is-as Vaubel (1997) has argued-one, which violates several important constitutional principles, including

31 For an extensive empirical analysis of a number of the public choice hypotheses, see Vaubel (1994). See also Nedergaard $(1991 ; 1995)$ as good examples of how to approach the subject and proceed with empirical analysis.

32 The number of European interest groups increased ten-fold from 59 in 1954 to 546 in 1984. Already a decade ago there were close to 3.000 lobby organizations and 10.000 lobbyists present in Brussels (Naets 1990). Simultaneously it is a fact that most European pressure groups (83 pct.) are involved in promoting the special interests of professions, industry and commerce, while only very few represent the broader groups of consumers and taxpayers (Peirce 1991a: 282, Table 4; Vaubel 1994: 175).

33 It has been estimated that when it comes to subsidies at least 72 percent of the budget of the European Union is spent of activities favoring interest groups (Vaubel 1994: 174). As concerns regulation it has been estimated that 78 percent of the pages of the Official Journal are devoted to special interest group legislation (Peirce 1991a: Table 2).

34 The size of the bureaucracy of the Commission has increased more than tenfold since 1960 and has more than quadrupled relative to the population, and there seems to be a noticeable increasing desire to become an employee of the Commission. At the same time the after-tax salaries of bureaucrats of the Commission are considerably higher than for comparable national civil servants (Vaubel 1995: 36-37). There is likewise evidence that members of the European Parliament systematically are more oriented towards spending than, e.g., the Council (Vaubel 1995: 38). 
the separation of powers, the subsidiarity principle and the democratic principle of an accountable and disposable administration. In addition it is one which as a result of wasteful rent-seeking produces excessive redistribution and regulation and hence welfare-losses.

But any reforms would have to be more than merely minor institutional engineering; it would have to be a comprehensive set of constitutional reforms which together would be able to change the dynamics of the process. The big challenge would be to construct such institutions which would be able to limit rentseeking behavior and increase the possibilities for welfare-increasing cooperation. Actually, there are good reasons why exactly a contractarian perspective might be extremely useful when analyzing what constitutional procedures might be preferable, especially now that the European Union seems to be moving towards a new constitutional phase. ${ }^{35}$

Most fundamentally it would seem that there is clear need for the introduction of a strict constitutional separation of the various branches of government at the Union-level. This should include a general strengthening of the elected branch (the Council of Ministers) relative to the bureaucratic branch (the Commission), e.g., by limiting or eliminating the Commission's power to propose legislation. Such a relative strengthening might also include the introduction of a second European chamber, in addition to the European Parliament, consisting of representatives of the parliaments of the individual member states.

The clearer separation of powers should, however, not only be between the various branches of government at the Union-level but also between the latter and the member-states. First and foremost there is an obvious need for the introduction of specific constitutional provisions governing secession by individual member states or for the opting-out. There should also be a strict and explicit interpretation of the subsidiarity principle and, for example, as it has been suggested, the creation of a second European "subsidiarity court" with the power to decide questions of conflict between the Union and the individual member states.

Another road which might be considered in a constitutional revision would be the introduction of fundamental rules clearly limiting the size of the Union-level government and its branches relative to that of the states, either directly by prohibitions or indirectly through institutional reforms. Direct restrictions could, e.g., be in the form of constitutional limits on the size of the central government, in terms of personnel and budget, relative to that of the member states. These could also include limitations on the salaries of employees of Commissions, in average as well as total expenditures, and restrictions on the salaries for the various positions, relative to that of comparable ones in the individual member states. Other such direct measures could include clear prohibitions against any restrictions upon freetrade, internally and externally, and given the progress towards economic-monetary

\footnotetext{
35 Some such constitutional rules with special relevance for Europe have been proposed and analyzed using a more or less explicit contractarian framework by, e.g., Buchanan (1990), Buchanan and Lee (1994), Vibert (1990a; 1990b), Vaubel (1994; 1995; 1997) and Mueller (1997). For a more general perspective of the solutions suggested by constitutional political economy, see Voigt (1997).
} 
union it would seem obvious to include restrictions upon the fiscal and monetary policies and an explicit prohibition against any form of debt issuing by the Union.

This could be supplemented by the introduction of more indirect measures, which could support a reduction of rent-seeking. This could include term-limits governing the election of members of the European Parliament and other Unionlevel offices, the appointment of Commissioners and other high-level bureaucrats, judges of the European Court, etc. The same kind of logic could be applied to the legislative process itself through the introduction of "sun-set" provisions, i.e., the automatic expiration of existing directives, regulations and expenditures. Simultaneously measures should be taken which would make it more difficult to pass new and rent-distributing legislation, e.g., a requirement of qualified majority for concurrent legislation, a requirement of unanimity between the states on expansion of the tasks of the European Union and an extensive use of referenda in the states for this purpose. Another tool would be to introduce democratic superrequirements on specific areas, e.g., such that increases in the Union budget would be subject to direct approval by a majority of the voters in the Union and in a majority of the states that are net-contributors to the expenditures, or unanimity on increases in spending and contributions from individual member states, possibly linked with referenda.

Several of such constitutional reforms might together be effective in taming the forces of rent-seeking, or at least contributing to doing so. But here we would seem to face a fundamental problem, which is but a variation of the Contractarian Paradox sketched here: The very process of taming the forces problematic for a cooperative European integration is itself vulnerable to rent-seeking. First of all, it seems to be well-established that no constitutional rule is incapable of being circumvented. If powerful players gang up on it and decide to ignore it, no constitutional restriction, absent of a requirement of virtual unanimity among all actors, can guarantee that things will work out the way they were envisioned. Second, to wit, any such institutional reforms would have to be implemented by exactly those groups which have very little interest in halting the process voluntarily. But if they do not want to do so voluntarily, and if they are essential for the change, then why should the support the change? In short: If the actors indeed are behaving like the inhabitants of a Hobbesian state-of-nature before entering into the integrated Europe, there would seem to be little reason why we should suddenly expect them to begin to behave differently.

The answer is, of course, that they will do so if and only if the institutional set-up is such that cooperation now becomes the dominant strategy of the game. In this respect public choice theory would seem to confront us with a problem of infinite regress: Every solution to a problem seems to presuppose the solution of a higher-order problem. It should, in other words, now become clear why there seems to be a genuine constitutional dilemma involved in the process of European integration. Or, as the old question goes, Quis custodiet custodes? 


\section{Summary}

The conclusion of the present study is not that there can be no normative defense of European integration, and neither is it that the rational choice approach is not useful in explaining the process. Rather the point is somewhat more limited one: That the process of European integration cannot be satisfactorily explained through a specifically contractarian approach. To achieve this another perspective is needed, and such one is close at hand in the rational choice approach, in the form of the public choice theory of rent-seeking.

\section{References}

Baldwin, David A., ed. 1993. Neorealism and Neoliberalism: The Contemporary Debate. New York: Columbia University Press.

Barry, Brian. 1965. Political Argument. London: Routledge \& Kegan Paul, 1972.

Bates, Robert H. 1988. Contra contractarianism: Some reflections on the new institutionalism. Politics and Society 16, 2-3 (September): 389-401.

Buchanan, James M. 1975. The Limits of Liberty: Between Anarchy and Leviathan. Chicago: University of Chicago Press.

Buchanan, James M. 1990. Europe's constitutional opportunity. In James Buchanan et al.: Europe's Constitutional Future. London: Institute of Economic Affairs: 1-20.

Buchanan, James M., and Dwight R. Lee. 1994. On a fiscal constitution for the European Union. Journal des Economistes et des Etudes Humaines 5: 219-32.

Christensen, Jørgen Grønnegaard. 1991. Den Usynlige Stat. København: Gyldendal.

Cowen, Tyler, and Gregory S. Kavka. 1991. The Public Goods Rationale for Government and the Circularity Problem. Unpublished manuscript, Department of Economics, George Mason University.

Green, Leslie. 1988. The Authority of the State. Oxford: Clarendon Press.

Grotius, Hugo. 1625. De Jure Belli et Pacis. Trans. The Rights of War and Peace, including The Law of Nature and of Nations. Washington: Walter Dunne, 1901.

Hampton, Jean. 1986. Hobbes and the Social Contract Tradition. Cambridge: Cambridge University Press.

Hampton, Jean. 1987. Free-rider problems in the production of collective goods. Economics and Philosophy 3 (September): 245-73.

Hobbes, Thomas. 1651. Leviathan. Cambridge: Cambridge University Press, 1991.

Hosli, Madeleine. 1995. The political economy of subsidiarity. In The Political Economy of European Integration. Ed. Finn Laursen. Hague: Kluwer Law International: 63-89.

Kalt, Joseph P. 1981. Public goods and the theory of government. Cato Journal 1 (Fall): 565-84.

Kavka, Gregory S. 1986. Hobbesian Moral and Political Theory. Princeton: Princeton University Press.

Kraus, Jody S. 1993. The Limits of Hobbesian Contractarianism. Cambridge: Cambridge University Press.

Kristensen, Ole P. 1980. The logic of political-bureaucratic decision-making as a cause of governmental growth. European Journal of Political Research 8: 249-64.

Kristensen, Ole P. 1987. Vaksten i den Offentlige Sektor: Institutioner og Politik. Copenhagen: Jurist- og Økonomforbundets Forlag.

Kurrild-Klitgaard, Peter. 1995. Political contractarianism and the prisoners' dilemma of the prisoners' dilemma, MS. Copenhagen: Institute of Political Science.

Kurrild-Klitgaard, Peter. 1997. Rational Choice, Collective Action and the Paradox of Rebellion. Copenhagen: Political Studies Press.

Locke, John. 1690. Two Treatises of Government. Ed. Peter Laslett. Cambridge: Cambridge University Press, 1988. 
Mueller, Dennis C. 1989. Public Choice II. Cambridge: Cambridge University Press.

Mueller, Dennis C. 1997. Federalism and the European Union: A constitutional perspective. Public Choice 92: 255-280.

Naets, G. 1990. Lobbying in the European Community. Business Journal (February): 20-21.

Narveson, Jan. 1988. The Libertarian Idea. Philadelphia: Temple University Press.

Nedergaard, Peter. 1991. Public choice og europæisk integration i 1980'erne. Politica 23, 2: 154-166.

Nedergaard, Peter. 1995. The political economy of CAP reform. In The political economy of European integration. Ed. Finn Laursen. Hague: Kluwer Law International: 111-144.

Olson, Mancur. 1965. The Logic of Collective Action: Public Goods and the Theory of Groups. Cambridge: Harvard University Press.

Ostrom, Elinor. 1990. Governing the Commons: The Evolution of Institutions for Collective Action. Cambridge: Cambridge University Press.

Peirce, William S. 1991a. Unanimous decisions in a redistributive context: The Council of Ministers of the European Communities. In The Political Economy of International Organizations: A PublicChoice-Approach. Eds. Roland Vaubel and Th.D. Willett. Boulder: Westview: 267-85.

Peirce, William S. 1991b. After 1992: The European Community and the redistribution of rents. Kyklos 44: 521-36.

Pufendorf, Samuel. 1672. De Jure Naturae et Gentium Libri Octo. Trans. On the Law of Nature and Nations. Oxford: Clarendon Press, 1934.

Pufendorf, Samuel. 1673. De Officio Hominis et Civis juxta Legem Naturalem Libri Duo. Trans. On the Duty of Man and Citizen According to Natural Law. Ed. James Tully. Cambridge: Cambridge University Press, 1991.

Rawls, John. 1971. A Theory of Justice. Cambridge: Harvard University Press.

Rothbard, Murray N. 1970. Power and Market: Government and the Economy. Kansas City: Sheed Andrews, 1977.

Schmidtz, David. 1988. Public goods and political authority. Philosophical Papers 17: 185-91.

Schmidtz, David. 1990. Justifying the state. Ethics 101 (October): 89-102.

Schmidtz, David. 1991. The Limits of Government: An Essay on the Public Goods Argument. Boulder: Westview Press.

Taylor, Michael. 1987. The Possibility of Cooperation. Cambridge: Cambridge University Press.

Teutemann, Manfred. 1990. Completion of the internal market: An application of public choice theory, Economic Paper No. 83. Brussels: The Directorate-General for Economic and Financial Affairs, Commission of the European Communities.

Tollison, Robert D. 1982. Rent seeking: A survey. Kyklos 35, 4: 575-602.

Tullock, Gordon. 1974. The Social Dilemma: The Economics of War and Revolution. Blacksburg: Center for Study of Public Choice.

Tullock, Gordon. 1993. Rent Seeking. Aldershot: Edward Elgar and The Locke Institute.

Vaubel, Roland. 1994. The political economy of centralization and the European Community. Public Choice 81: 151-90.

Vaubel, Roland. 1995. The Centralisation of Western Europe: The Common Market, Political Integration, and Democracy. London: Institute of Economic Affairs.

Vaubel, Roland. 1996. Constitutional safeguards against centralization in federal states: An international cross-section analysis. Constitutional Political Economy 7: 79-102.

Vaubel, Roland. 1997. The constitutional reform of the European Union. European Economic Review 41: 443-50.

Vibert, Frank. 1990a. Europe's constitutional deficit. In James Buchanan et al.: Europe's Constitutional Future. London: Institute of Economic Affairs: 69-95.

Vibert, Frank. 1990b. The new Europe: Constitutionalist or centralist?. In James Buchanan et al.: Europe's Constitutional Future. London: Institute of Economic Affairs: 121-44.

Voigt, Stefan. 1997. Positive constitutional economics: A survey. Public Choice 90: 11-53. 